\title{
Endocentric Phrases in Mesut Kurtis' album Tabassam (2004): Tagmemeik Kenneth Lee Pike
}

\begin{abstract}
Arina Haque ${ }^{1}$,E-mail: haquepokok@gmail.com, UIN Maulana Malik Ibrahim Malang, Indonesia Rusda Fauziah Azzadi², E-mail: $17310018 @$ student.uin-malang.ac.id, UIN Maulana Malik Ibrahim Malang, Indonesia Iffat Maimunah ${ }^{\mathbf{3}}$, E-mail: iffatmaimunah@uin-malang.ac.id, UIN Maulana Malik Ibrahim Malang, Indonesia
\end{abstract}

\section{(c) (1) (2)}

This is an open-access article under the CC-BY-SA license

(C2021 by the authors. Submitted for possible open access publication under the terms and conditions of the Creative Commons Attribution-ShareAlike 4.0 International License-(CC-BY-SA) (https://creativecommons.org/licenses/by-sa/4.0/)

do) DOI: bttp://dx.doi.ong/10.30983/buruf.v1i1.4940

\begin{tabular}{l|l|l|} 
Submission: August 30, $2021 \quad$ Revised: December 12, 2021 & Published: December 31, 2021 \\
\hline
\end{tabular}

\begin{abstract}
The purpose of this research is to describe the form of endocentric phrases in Mesut Kurtis' Tabassam album and to describe its construction based on Kenneth Lee Pike's tagmemic units. This research is qualitative descriptive research, with the data source of the song lyrics in Mesut Kurtis' Tabassam album. The data collection technique uses the reading-note technique. Data validation techniques by increasing persistence, triangulation, and discussion. Data analysis techniques by collecting data, processing data, reading the entire data, grouping data, and describing the data. The results of this study reveal that the song lyrics on the Tabassam Album by Mesut Kurtis, which consists of 13 songs, contain endocentric phrases with three types, namely: (1) attributive endocentric phrases with a total of three phrases; (2) a three-phase coordinative endocentric phrase; and (3) a positive endocentric phrase with a single phrase. The three types of phrases have various structures.
\end{abstract}

Keywords: Endocentric, Mesut Kurtis, noun phrases

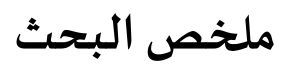

الغرض من هذا البحث هو وصف شكل العبارات المركزية في ألبوم مسعود كورتيس تباسم ووصف بنائه بناءً على وحدات تغميميك لكينيث لي بايك. هذا البحث هو بحث وصفي نوعي ، بمصيدر بيانات كلمات الأغنية في ألبوم مسعود كرتيس تبسم. تستخدم تقنية جمع البيانات أسلوب قراءة الملاحظات. تقنيات التحقق من صحة البيانات عن طريق زيادة المثابرة والتثليث والمناقشـة. تقنيات تحليل البيانات من خلال جمع البيانات ومعالجة البيانات وقراءة البيانات بالكامل وتجميع البيانات ووصف البيانات. وتكشف نتائج هذه الدراسـة أن كلمات الأغنية في ألبوم تباسم لمسعود كيرتس ، والمكونة من 13 أغنية ، تحتوي على جمل مركزية ذات ثلاثة أنواع ، وهي: (1) جمل منسوبة داخلية بمجموع ثلاث جمل. (2) عبارة مركزية داخلية تنسيقية ثلاثية المراحل ؛ و (3) عبارة 


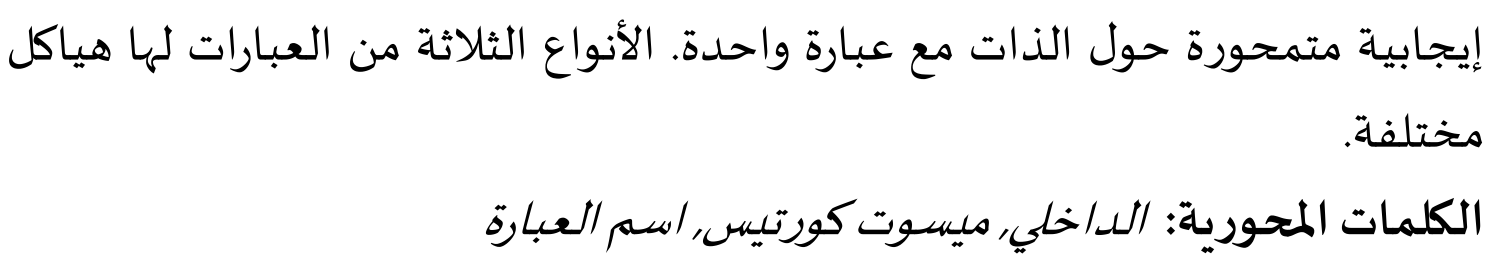

\section{INTRODUCTION}

Research studies on the construction of noun phrases are an area of linguistic discipline that tends to be of interest to modern linguistic observers. Grammar studies are often studied in various languages, such as English; ${ }^{1}$ Japanese language ${ }^{2}$ also Indonesian itself. ${ }^{3}$ The selection of the object of this research study refers to an Arabic literary work, namely the album Tabassam by Mesut Kurtis, which was released in 2014. The album by Mesut Kurtis is one of the most popular, with its fusha or formal language style. But unfortunately, there are still few grammatical studies that collaborate with grammar and Arabic linguistic constructions in the arrangement of words and sentences in songs. The uniqueness and interest of this study are that people who love Arabic nasyid songs can absorb the meaning and lafadz and enjoy the results of an in-depth study in this grammatical discipline.

The songs in this album by Mesut Kurtis fit perfectly with the theory of endocentric noun phrase construction with tagmemic grammar based on Kenneth Lee Pike's perspective. Each lyric in the song stanza contains many endocentric phrases so that it is continuous with the tagmemic theory, which examines the minor elements in the grammatical structure of language. Likewise with murakkab isnadi can be in line with the phrase. This research will collaborate the two theories in analyzing and discussing the results of the data found in the song's verses.

In line with the theory and objects that we used in this study, we found several studies that have been carried out. Junaid's research (2018) A Syntactic Analysis of the English Noun Phrase (A Study at The Fifth Semester Of English Department Faculty Of Teacher Training And Education University Of Muhammadiyah Makassar). Junaid's research revealed that students used 32 patterns of noun phrase formation which were included in the construction of accuracy and inaccuracy. Hidayah's Research, Arini (2015) English Attributive Endocentric Actors Noun Phrases in Hotel Front Office. Hidayah's research describes the categories of noun phrases forming attributive endocentric actors in English terms at the hotel's front office with two categories: attributive that precedes the central element with 13 data and the central element precedes the attribute with 2 data. ${ }^{4}$ Hasyim's research, Muhammad (2020) Syntactic construction

${ }^{1}$ Arini Hidayah, "Frase Nomina Pelaku Endosentris Atributif Bahasa Inggris di Bidang Kantor Depan (Front Office) Hotel," Haluan Sastra Budaya 3, no. 2 (nd): 105-17; Junaid Junaid, “A syntactic Analysis of The English Noun Phrase (A Study at The Fifth Semester of English Department Faculty of Teacher Training and Education University of Muhammadiyah Makassar)," Perspektif: Jurnal Pengembangan Sumber Daya Insani 3, no. 1 (2018): 317-26.

${ }^{2}$ Lina Rosliana, “Frasa Endosentris Pada Bahasa Jepang," Izumi 4, no. 1 (2015): 51-56.

${ }^{3}$ Muhammad Hasyim, Asbarin Asbarin, and Hammadul Azhim, "Konstruksi Sintaksis Dalam Novel" Bumi Cinta" Karya Habiburrahman El Shirazy Berdasarkan Perspektif Tagmemeik Kenneth L. Pike," 2020.

${ }^{4}$ Arini Hidayah, "Frase Nomina Pelaku Endosentris Atributif Bahasa Inggris Di Bidang Kantor Depan (Front Office) Hotel," Haluan Sastra Budaya 3, no. 2 (n.d.): 105-17. 
in the novel Bumi Cinta by Habiburrahman El Shirazy based on Kenneth Lee Pike's Tagmemic Perspective. The results of this study were the discovery of 5 Ayyas conversations containing $\mathrm{S}+\mathrm{P}+\mathrm{O}+\mathrm{K}, 6 \mathrm{~S}+\mathrm{P}+\mathrm{O}, 1 \mathrm{~S}+\mathrm{P}+\mathrm{K}$, and $2 \mathrm{~S}+\mathrm{Pel} .^{5}$

Some of the studies that have been carried out certainly have similarities and differences with our research study. The difference lies in the object of the research study. The similarity lies in the theory used. Therefore, the position of this research is a new study designed to improve and add to the study in the realm of modern linguistic research. In line with this, our research focuses on describing the form of endocentric noun phrases in Mesut Kurtis' album Tabassam and describing their construction based on Kenneth Lee Pike's tagmemic unit.

Based on the construction, phrases are divided into endocentric phrases and exocentric phrases. Phrases that have a natural element are called endocentric phrases. Endocentric phrases have similarities in the distribution of elements, both all elements and one of them. ${ }^{6}$ An endocentric phrase is a phrase in which one of its elements or components has the same syntactic behavior as the whole. ${ }^{7}$ Endocentric phrases can be divided into three types, namely attributive, coordinating, and appositive. ${ }^{8}$ Parera stated that attributive endocentric phrases are endocentric phrases that have an element that acts as the center and another element as an attribute. ${ }^{9}$ Coordinative Endocentric Phrases are endocentric phrases that have many nuclei. ${ }^{10}$ Appositive endocentric phrases belong to the same category as coordinating endocentric phrases, which are endocentric phrases that have many parents. ${ }^{11}$ Phrase tagmeme has slots filled by several categories of words, such as nominal, pronominal, verbal, adjective, numeral, and others. Attributes or elements that build phrases apart from the phrase's core can also be in the form of conjunctions, prepositions, and other conjunctions. ${ }^{12}$ In noun phrases, the building blocks used are noun categories or isms. This study focuses on endocentric phrases with noun coverage because the song lyrics on the Tabassam album tend to use these types of phrases.

The methodology of this research is qualitative and descriptive. The data used in this study is the primary data source in songs in the album Tabassam by Mesut Kurtis, which was released on July 7, 2014, by Awakening Records. In it there are 13 songs, including: Rouhi Fidak as the first song in this album, Tabassam, Alhamdulillah, Adnani, Ghar Hira, Eidun Said ft. Maher Zain, Assalatu Wassalam, Ya Man Bihayly Dawman, Seyreyle Guzel, Farha, Ataytu Bidthamby, and Du'a. Data collection techniques used are reading and note-taking techniques. Data validation techniques are carried out to test the

\footnotetext{
5 Hasyim, Asbarin, and Azhim, "Konstruksi Sintaksis Dalam Novel" Bumi Cinta" Karya Habiburrahman El Shirazy Berdasarkan Perspektif Tagmemeik Kenneth L. Pike."

${ }^{6}$ Muhammad Ramlan, Ilmu Bahasa Indonesia: Sintaksis (UP Karyono, 1981).

7 Georg Hincha, "Endocentric vs. Exocentric Constructions," Lingua, 1961, https://doi.org/10.1016/0024-3841(61)90132-2.

8 Masayoshi Shibatani, "Syntax (General)," in International Encyclopedia of the Social \& Behavioral Sciences: Second Edition, 2015, https://doi.org/10.1016/B978-0-08-097086-8.52033-9.

${ }^{9}$ Jos Daniel Parera, "Sintaksis (Edisi Kedua)," Jakarta: PT Gramedia Pustaka Utama, 1988.

${ }^{10}$ Ahmad Husin and Roihanah Husin, "Peran Teori Tagmemeik Dalam Pembelajaran Sastra Anak Khususnya Penggunaan Media Lagu-Lagu Dolanan,” JURNAL PUSAKA 2, no. 2 (2015).

${ }^{11}$ Rosliana, "Frasa Endosentris Pada Bahasa Jepang."

12 J. Anitha, J. Saritha, and Namkyun Baik, "Payroll Processing Tagmemics in SAP HR," International Journal of Advanced Science and Technology 111 (2018), https://doi.org/10.14257/ijast.2018.111.06.
} 
validity of data to obtain valid data from the source of the data obtained. ${ }^{13}$ The researcher used the technique of reduction, triangulation, and increased persistence invalidation. Meanwhile, data analysis involves collecting raw data, processing data for later analysis, reading the entire data, grouping or coding the data according to need, describing related themes, and interpreting the meaning of the theme.

\section{RESEARCH METHODS}

This research is qualitative descriptive research, with the data source of the song lyrics in Mesut Kurtis' Tabassam album. The data collection technique uses the readingnote technique. Data validation techniques by increasing persistence, triangulation, and discussion. Data analysis techniques by collecting data, processing data, reading the entire data, grouping data, and describing the data.

\section{FINDINGS AND DISCUSSION}

An endocentric phrase is grammatical which has two or more words in it. It consists of a core element or central element (UP), which is the main most crucial element, and an attributive element (Ar) that supports the core element as an explanatory or complementary. ${ }^{14}$ The following describes the endocentric phrase with its three divisions in Mesut Kurtis' album Tabassam and its construction based on Kenneth Lee Pike's tagmemic unit.

\section{Attributive Endocentric Phrases in Tabassum Album}

The construction of attributive endocentric phrases in Arabic rules is also called tarkib idhofi and tarkib washfi. ${ }^{15}$ There are 3 phrases endocentric existing attributive found in the lyrics of the song on the album Mesut Kurtis Tabassam work are summarized in the table below:

Table 1. Forms endocentric phrase attributive

\begin{tabular}{lc}
\multicolumn{1}{c}{ Elements grammar } & $\begin{array}{c}\text { phrase } \\
\text { Shapeattributive }\end{array}$ \\
\hline phrase endocentric with adjectives (washfi) & عيد سعيد \\
\hline endocentric the phrase pronouns (idhofi) لبدين & \\
\hline
\end{tabular}

In Table 1. There are three forms of attributive endocentric phrases with pronouns (idhofi) and two forms of endocentric phrases with adjectives (washfi). So that the phrase construction in attributive endocentric includes two forms of construction, namely attributive phrase construction with pronouns and attributive phrase construction with adjectives.

${ }^{13}$ R. Bogdan and S Knopp, "Qualitative Research for Education," Qualitative Research, 2003, https://doi.org/10.1177/1468794107085301.

${ }^{14}$ Ramlan, Ilmu Bahasa Indonesia: Sintaksis.

${ }^{15}$ Walter Anthony Cook, Introduction to Tagmemic Analysis (Holt McDougal, 1969). 


\section{Construction of Attributive Endocentric Phrases with Adjectives (Washfi)}

Endocentric phrases with adjectives are phrases in which there are core elements of adjectives as supporting words of the central element. This phrase is a kind of attributive noun phrase, which is the development of the core phrase. The developer also describes in detail what is meant by the common central elements.

\section{( عيد سعيد) ( )}

The following is a description of the phrase tagmeme in the construction of attributive endocentric phrases with adjectives:

Table 2. Examples of attributive endocentric phrases with adjectives (Washfi)

\begin{tabular}{ccc}
\hline Phrases & $($ (عيد) & $($ (سعيد) \\
\hline Translation of & Holidays & Happy \\
\hline Category & Ism & Ism Nature \\
\hline Function & Central Element (UP) ) & Attribute (Ar) The \\
\hline
\end{tabular}

Phrase (عيد سعيد), which means "Happy holidays" is located at the beginning of the song lyrics. It is called an attributive endocentric phrase because its components are nouns or isims that contain one core. One noun is the central element (UP), and the other is an adjective explaining the previous noun. It is classified as an attributive endocentric phrase with an adjective because the attribute uses an adjective (Isim Properties). The translation of the formula is as follows:

FEAr (Tarkib Washfi) $=\mathrm{I}+\mathrm{S} / \mathrm{N}+$ Adj

FEAr (attributive endocentric phrase) or in Arabic called tarkib washfi consists of Ism (noun) or a noun as the central element (UP) and is explained by Ism The nature (Adjective) or adjective as an attribute (Ar) of the core element. The central tagmeme is the core of the tagmeme (nuclear) or the central element and is mandatory by Ism. The following is a tagmeme system with its four elements described in the chart below:

Diagram 1. Attributive Endocentric Phrase Tagmeme

\begin{tabular}{|c|c|}
\hline Slot & Class \\
\hline (عيد سعيد) & (عيد سعيد) \\
\hline "Нарру" & 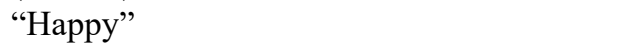 \\
\hline holidaysFEAr (Tarkib Washfi) $=\mathrm{Up}+\mathrm{Ar}$ & holidaysFEAr (Tarkib Washfi) = I + S \\
\hline $\begin{array}{l}\text { Slot (Up) is the core of the phrase and the } \\
\text { slot ( Ar) is an attribute of the phrase }\end{array}$ & $\begin{array}{l}\text { Class fills the slot with one Ism and one trait } \\
\text { ism (which indicates the nature of Ism) }\end{array}$ \\
\hline Role & Cohesion \\
\hline 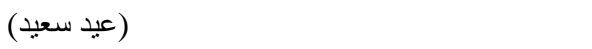 & (عيد سعيد) \\
\hline "Holiday the happy ones" The & "Happy holidays" \\
\hline $\begin{array}{l}\text { two core phrases have the same tagmeme } \\
\text { role }\end{array}$ & $\begin{array}{l}\text { Cohesion is a parallel meaning of the same } \\
\text { core }\end{array}$ \\
\hline
\end{tabular}

Based on Diagram 1. Coordinative Endocentric Phrase Tagmeme depicted four tagmemic elements in it:

a. Slot. In the first dimension, the phrase slot builds a structure with the first arrangement. The phrase (عيد) has a slot built by the central element structure and attributes in adjectives. (FEAr(Tarkib Washfi) $=\mathrm{I}+\mathrm{S} / \mathrm{N}+\mathrm{Adj})$. The slot that is one of the characteristics of tagmeme is a space in its structure filled by the tagmeme function. Meanwhile, the tagmeme function in the phrase is in the form of the nucleus 
and the outside of the core (margin). Slots are the same as functions or sentence positions. The fulfillment of the slot with the core of the phrase being the central element (Up) in the phrase (عيد) (عيد), which means a holiday or Eid day while outside the core is an adjective that follows it (سعيد) which means happy. To compose the words of a happy Hari Raya.

b. Class. In the class dimension, the phrase tagmeme fills the slots with both categories. The phrase class is filled with lingual units such as words, morphemes, and phrases. These lingual units are class categories. Classes can be further broken down into subclasses or smaller classes. In phrases, classes can be broken down into noun phrases (nouns) and verb phrases (verbs). The phrase (عيد سعيد) is a noun phrase. In the second dimension, the class consists of two categories, namely Ism (عيد) as the central element and isim Properti (سعيد) as a supporting element that fulfills the position of the tagmeme class.

c. Role. In the role dimension, the phrase tagmemic is carried by the tagmemic function. Roles are tagmemic markers or traits that are carriers of the tagmemic function. The phrase (عيد) of each tagmemic has a role as an actor. The ism class category acts as the central element actor (Up). While the isim shifat becomes the modifier that limits and develops the meaning of the central element. (عيد)is the carrier of the core function (nucleus) and (سعيد) carries the function outside the nucleus (margin). In endocentric phrases, semantically, the phrase (عيد) has an equivalent function between its central elements.

d. Cohesion. In the fourth dimension, cohesion becomes the controller of continuity in the tagmemic-tagmeme in the phrase. The cohesion of tagmemic in this phrase is the equivalence of the distribution of meaning between the modifier and the phrase's core.

\section{Construction of Attributive Endocentric Phrases with Pronouns}

Endocentric phrases with pronouns are phrases with core elements of pronouns as supporting words of the central element. ${ }^{16}$

(ق)بي)

The following is a description of the phrase tagmeme in the construction of attributive endocentric phrases with pronouns:

Table 3. Attributive endocentric phrases with pronouns

\begin{tabular}{ccc}
\hline Phrases & (قلب) & (ي) \\
\hline Translation of & Hati & Ku (possession) \\
\hline Category & Ism & $\begin{array}{l}\text { Ism Dhomir } \\
\text { (possession) }\end{array}$ \\
\hline
\end{tabular}

Phrases (قلبي) which means “My heart” is located in the sentence (ودواء قلبي). It is called an attributive endocentric phrase because the element consists of a noun or Ism which contains a single nucleus. One noun is the central element (UP) and the other is a possessive pronoun that describes the ownership of the previous noun. It is classified as an attributive endocentric phrase with a pronoun because the attribute uses a pronoun (Isim Dhomir). The formula is as follows:

\footnotetext{
${ }^{16}$ Hincha, "Endocentric vs. Exocentric Constructions."
} 


\section{Explanation of the FEAr (Tarkib Idhofi $)=\mathrm{I}+\mathrm{Dh} / \mathrm{N}+$ ProN}

The explanation is, FEAr (attributive endocentric phrase) or in Arabic called tarkib Idhofi consists of Ism (noun) or a noun as the central element (UP) and is described by Isim Dhomir (Pronoun) or possessive pronoun as an attribute (Ar) of the core element. The central tagmemic is the core of the tagmemic (nuclear) or the central element and is mandatory by Ism. The following is a tagmemic system with its four elements described in the chart below:

Diagram 2. Attributive endocentric phrase tagmeme

\begin{tabular}{ll}
\hline $\begin{array}{l}\text { Slot } \\
\text { (قلب) }\end{array}$ "Hatiku" & $\begin{array}{l}\text { Class } \\
\text { (قلبي) } \\
\text { "My heart" }\end{array}$ \\
$\begin{array}{l}\text { FEAr (Tarkib Idhofi) = Up + Ar } \\
\text { Slot (Up) is the core phrase, and slot (Ar) is } \\
\text { an attribute as a descriptor }\end{array}$ & $\begin{array}{l}\text { FEAr (Tarkib Idhofi) = I + Dh } \\
\text { It consists of one ism and one ism dhomir } \\
\text { (which indicates the ownership of the } \\
\text { Ism)tagmeme }\end{array}$ \\
\hline Role & $\begin{array}{l}\text { Cohesion } \\
\text { (قلبي) }\end{array}$ \\
"My heart" & $\begin{array}{l}\text { "My heart" The } \\
\text { the cohesion of the two words in parallel and } \\
\text { The roles of the two core phrases have an and } \\
\text { equivalent and interrelated linked }\end{array}$ \\
\hline
\end{tabular}

Based on Diagram 2. Attributive Endocentric Phrase Tagmeme depicted four tagmemic elements in it:

a. Slot. In the first dimension, phrase slots build a structure with the first arrangement, phrases (قلبي) has a slot built by the central element structure and attributes in the form of pronouns FEAr (Tarkib Idhofi) $=\mathrm{I}+\mathrm{Dh} / \mathrm{N}+$ ProN Slot which is one of the characteristics of tagmemic in the form of empty space in the structure which is filled by the tagmemic function. Meanwhile, the tagmemic function in the phrase is in the form of the nucleus and the outside of the core (margin). Slots are the same as functions or sentence positions. Fulfillment of the slot with the core phrase being the central element (Up) in the phrase (قلب) is (قلب) which means heart while outside the core is pronominal or possession (ي) which means mine. So that the words of my heart.

b. Class. In the class dimension, the phrase tagmemic fills the slots with both categories. The phrase class is filled with lingual units such as words, morphemes, and phrases. These lingual units are class categories. Classes can be further broken down into subclasses or smaller classes. In phrases, classes can be broken down into noun phrases (nouns) and verb phrases (verbs). Phrases (قلبي) are noun phrases. In the second dimension, the class consists of two categories, namely Ism (قلب) as the central element and pronouns (ي) as supporting elements that fulfill the position of the tagmemic class.

c. Role. In the role dimension, the phrase tagmemic is carried by the tagmemic function. Roles are tagmemic markers or traits that are carriers of the tagmemic function. The phrase (قلبي) of each tagmemic has a role as an actor. The ism class category acts as the central element actor (Up). While the isim shifat becomes the modifier that limits and develops the meaning of the central element. (قلب)is the carrier of the core function (nucleus), and (ي) carries the function outside the nucleus (margin). In 
endocentric phrases, semantically the phrase (قلبي) has an equivalent function between its central elements.

d. Cohesion. Cohesion is the controller of continuity in tagmemics-tagmeme in phrases. The cohesion of tagmeme in this phrase is the equivalence of the distribution of meaning between the modifier and the phrase's core.

\section{Coordinative Endocentric Phrases Construction in Tabassam Album Coordinative}

Endocentric phrases are phrases that are composed of a combination of words with the same or parallel position so that each of the words that make up this phrase is the core of the phrase or the main word. ${ }^{17}$ In Arabic rules, the endocentric phrase construction is called tarkib 'athfi. There are three coordinating endocentric phrases found in the song lyrics on Mesut Kurtis' Tabassam Album, which are summarized in the table below:

Table 4. Coordinative Endocentric Phrases Forms Coordinative

\begin{tabular}{|c|c|}
\hline Phrases & Classification \\
\hline Endocentric with development & الإسلام و الإيمان , نُور أ وهُدى \\
\hline Endocentric phrases with opposition & السر و الإعلان \\
\hline
\end{tabular}

In Table 4. the forms of coordinating endocentric phrases, there are two forms of phrases classified as endocentric phrases with development, and one includes endocentric phrases with opposition.

\section{Construction of Coordinative Endocentric Phrases with Development Coordinative}

Coordinative phrases with development are endocentric noun phrases with coordinates in the form of core phrase developers. The developer is also the phrase's core that explains or explains the translation of the core of other phrases. The modifier in this phrase is just conjunction that is between the two core phrases. ${ }^{18}$

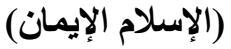

The phrase (الإسلام الإنسان) is one of the phrases that the researcher found in the song lyrics of Mesut Kurtis' Tabassam Album. This phrase belongs to the category of coordinating endocentric phrases with development. The phrase (الإسلام الإيمان) means the translation of Islam and faith in Indonesian. The classification of this phrase into an endocentric phrase is due to the similarity in the distribution of its meaning. It is classified as a coordinative classification because it has more than one central element. While the classification into development is because faith is the development of Islam.

Here is the translation of the phrase in the construction phrase tagmemes endocentric coordinate with development:

Table 5. Form endocentric Coordinating phrase

\begin{tabular}{cccc}
\hline phrase & $($ الإيمان) & $($ ) & $($ ) \\
\hline Translation: & Islam & And & Faith \\
\hline Categories & Ism & Harf Athaf & Ism \\
\hline Function & ElementCenter & Hubung word & Element Fitness \\
\hline
\end{tabular}

${ }^{17}$ Linda Flower and John R. Hayes, "The Cognition of Discovery: Defining a Rhetorical Problem," College Composition and Communication, 1980, https://doi.org/10.2307/356630.

18 James R Martin, "Text and Clause: Fractal Resonance," Text-Interdisciplinary Journal for the Study of Discourse 15, no. 1 (1995): 5-42. 
Phrase (الإسلام والإيمان) is located in the sentence (حقا على الإسلام الإيمان)true which means the truth of Islam and faith. The structure of the type of coordinating endocentric phrase with development in the two central elements is as follows:

FEKo (tarkib 'athfi) $=\mathrm{I}+\mathrm{A}+\mathrm{I}$

In the formula it is explained that FeKo (coordinative endocentric phrase) or in Arabic terms is called tarkib 'athfi is composed of tagmeme I (Ism) as Up (central element) then tagmeme A ('Athaf) as conjunction and another tagmeme I (Ism) as Up (central element) the second. The central tagmeme is the core of the tagmeme (nuclear) or the central element and is mandatory by Ism. The unit of the tagmeme system with its four elements is described in the following chart:

Diagram 3. The tagmeme of the coordinating endocentric phrase

\begin{tabular}{|c|c|}
\hline Slot & Class \\
\hline (الإسلام الإيمان) & (الإسلام الإيمان) \\
\hline "Islam and Iman" & "Islam and Faith" \\
\hline $\mathrm{FEKo}=\mathrm{Up}+\mathrm{Kh}+\mathrm{Up}$ & FEKo $=\mathrm{I}+\mathrm{M}+\mathrm{I}$ \\
\hline Slot (Up) both are the core of the phrase & It consists of two isms and one harf 'athaf \\
\hline Role & Cohesion \\
\hline الإسلام الإيمان) & 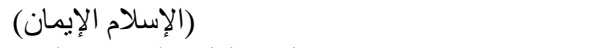 \\
\hline "Islam and Iman" & "Islam and Faith" The \\
\hline $\begin{array}{l}\text { The roles of each of these tagmeme phrases } \\
\text { are actors. }\end{array}$ & $\begin{array}{l}\text { the cohesion of this phrase is the } \\
\text { equivalence of the two main elements. }\end{array}$ \\
\hline
\end{tabular}

Based on diagram 3. Coordinative Endocentric Phrase Tagmeme is clearly illustrated by four scopes of phrase tagmeme with slot, class, role, and cohesion. Here's the description:

a. Slots. In the first dimension, namely slots, phrases (الإسلام الإيمان) have slots which are constructed by a structure with the arrangement of central elements, conjunctions, and other central elements $(\mathrm{FEKo}=\mathrm{Up}+\mathrm{Kh}+\mathrm{Up})$. The slot that is one of the characteristics of tagmeme is an empty space in its structure filled by the tagmeme function. ${ }^{19}$ Meanwhile, the tagmeme function in the phrase is in the form of the nucleus and the outside of the core (margin). Slots are the same as functions or sentence positions. The fulfillment of the slot with the core of the phrase which is the central element (Up) in the phrase (الإسلام الإيمان) is (الإنان) which means Islam and (الإيمان) which means faith. In contrast, the outer core is conjunction (Kh), namely (وم) which means and.

b. Class. In the class dimension, the phrase tagmeme fills the slot with its three categories: isim, harf 'athaf, and isim maushul. Class is a feature of tagmeme in the form of an actual form of slot filler. Classes in phrases are filled with lingual units such as words, morphemes, and phrases. These lingual units are class categories. Classes can be further broken down into subclasses or smaller classes. In phrases, classes can be broken down into noun phrases (nouns) and verb phrases (verbs). Phrases (الإسلام الإيمان) are noun phrases. The class category that fills this phrase is isim, namely (الإسلام، الإيمان) in the central element slot (Up) and harf 'athaf, namely the phrase (و) in the conjunction (Kh).

${ }^{19}$ Walter R. Bodine and David Allan Dawson, "Text-Linguistics and Biblical Hebrew," Journal of the American Oriental Society, 1997, https://doi.org/10.2307/605294. 
c. Role. In the role dimension, the phrase tagmeme is carried by the tagmeme function. Roles are tagmeme markers or traits that are carriers of the tagmeme function. The phrase (الإسلام الإيمان) each tagmeme has a role as an actor. The ism class category acts as the central element actor (Up). Meanwhile, harf 'athaf becomes the modifier that limits and develops the meaning of its central element. (الإسلاح, الإيمان) into the carrier core functions (nucleus) and(و)brings functionality beyond the core (margin). In endocentric phrases, semantically the phrase (الإسلام الإيمان) has an equivalent function between its central elements.

d. Cohesion. Cohesion in the coordinating endocentric phrase is the equivalence of the meaning of the main elements of the two isms.

(نُوراً و هُدى)

The phrase (نُوراً) is one of the phrases that the researcher found in the song lyrics of Mesut Kurtis' Tabassam Album. This phrase belongs to the category of coordinating endocentric phrases with development. The phrase (نُوراً) means the translation of light and guidance in Indonesian. The classification of this phrase into an endocentric phrase is due to the similarity in the distribution of its meaning, and is classified as a coordinative classification because it has more than one central element. While the classification into development is because the instructions are the development of light.

Here's the translation of the phrase in the construction phrase tagmemes endocentric coordinate with development:

Table 6. Forms Coordinating endocentric phrase

\begin{tabular}{cccc}
\hline phrase & $($ (s) & $(g)$ & $($ ( ) $)$ \\
\hline Translations & Hints & And & Light \\
\hline Category & Ism & Harf Athaf & 'Ism \\
\hline Function & ElementCenter & Hubung word & Element Fitness \\
\hline
\end{tabular}

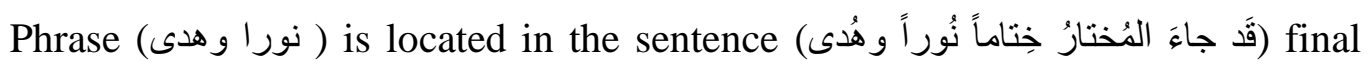
which means Mukhtar has come as the messenger who gives light and guidance. The structure of the type of coordinating endocentric phrase with development in the two central elements is as follows:

FEKo (tarkib 'athfi) $=\mathrm{I}+\mathrm{A}+\mathrm{I}$

In the formula it is explained that FeKo (coordinative endocentric phrase) or in Arabic terms is called tarkib 'athfi is composed of tagmeme I (Ism) as Up (central element) then tagmeme A ('Athaf) as conjunction and another tagmeme I (Ism) as Up (central element) the second. The central tagmeme is the core of the tagmeme (nuclear) or the central element and is mandatory by Ism. The system unit tagmemes with four elements are described in the following diagram:

Diagram 4. Coordinating endocentric phrase tagmemes

\begin{tabular}{|c|c|}
\hline $\begin{array}{l}\text { Slot } \\
\text { "light and guidance" feko }=\mathrm{Up}+\mathrm{Kh}+\mathrm{Up} \\
\text { "lot }(\mathrm{Up}) \text {, both of which are core phrase } \\
\text { Slot }\end{array}$ & 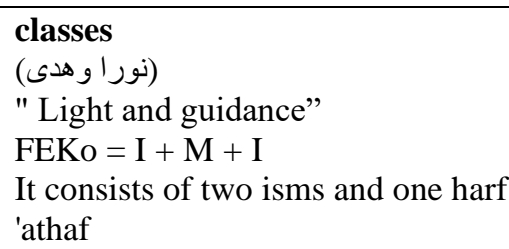 \\
\hline
\end{tabular}




\begin{tabular}{|c|c|}
\hline $\begin{array}{l}\text { Role } \\
\text { (نوراوهدى) } \\
\text { "Light and guidance" }\end{array}$ & $\begin{array}{l}\text { Cohesion } \\
\text { (نوراوهدى)" } \\
\text { "Light and guidance" }\end{array}$ \\
\hline $\begin{array}{l}\text { The role of each tagmeme of this phrase is as } \\
\text { an actor. }\end{array}$ & $\begin{array}{l}\text { The cohesion of coordinating } \\
\text { endocentric phrases is the equivalence } \\
\text { of the two main elements. }\end{array}$ \\
\hline
\end{tabular}

Based on Diagram 4. Coordinative Endocentric Phrase Tagmeme is clearly illustrated by four scopes of phrase tagmeme with slot, class, role, and cohesion. Here's the description:

a. Slots. In the first dimension, namely the slot, the phrase (نوراو هدى) has a slot built by a structure with the arrangement of central elements, conjunctions, and other central elements $(\mathrm{FEKo}=\mathrm{Up}+\mathrm{Kh}+\mathrm{Up})$. The slot that is one of the characteristics of tagmeme is an empty space in its structure filled by the tagmeme function. Meanwhile, the tagmeme function in the phrase is in the form of the nucleus and the outside of the core (margin). Slots are the same as functions or sentence positions. The fulfillment of the slot with the core of the phrase which is the central element

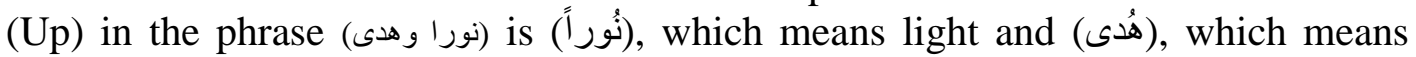
guidance. At the same time, the outside is essentially the conjunctions (Kh), namely(g)meaningful.

b. Class. In the class dimension, the phrase tagmeme fills the slot with its three categories: isim, harf 'athaf, and isim maushul. Class is a feature of tagmeme in the form of a natural form of slot filler. Classes in phrases are filled with lingual units such as words, morphemes, and phrases. These lingual units are class categories. Classes can be further broken down into subclasses or smaller classes. In phrases, classes can be broken down into noun phrases (nouns) and verb phrases (verbs). The phrase (نوراو هدى) is a noun phrase. The class category that fills this phrase is Ism, namely (هدى , نورا ( ندرى)in the central element slot (Up) and harf 'athaf, namely the phrase (g) in the conjunction (Kh).

c. Role. In the role dimension, the phrase tagmeme is carried by the tagmeme function. Roles are tagmeme markers or traits that are carriers of the tagmeme function. The phrase (نُوراً) of each tagmeme has a role as an actor. The ism class category acts as the central element actor (Up). Meanwhile, harf 'athaf becomes the modifier that limits and develops the meaning of its central element. (نورا, هدى) into the carrier core functions (nucleus) and(و)brings functionality beyond the core (margin). In endocentric phrases, semantically the phrase (نُوراً) has an equivalent function between its central elements.

d. Cohesion. In the fourth dimension, cohesion becomes the controller of continuity in the tagmeme-tagmeme in the phrase. Cohesion is a tagmeme marker that has a connecting control between tagmeme. The controller of the coordinating endocentric relationship is the equivalence of the meaning of the main elements of the two isms.

\section{Coordinative Endocentric Phrase Construction with Opposition}

Phrases are composed of the core of the phrase and modifiers or other words that change the meaning of the word in its construction. ${ }^{20} \mathrm{~A}$ coordinating phrase with the opposition is one kind of endocentric noun phrase with coordinates in the form of opposition from each core phrase. The core of the phrase becomes the opposite or

\footnotetext{
${ }^{20}$ Bodine and Dawson.
} 
opposite of the core of another phrase. The existence of a conjunction between the two core phrases is not always ordinary or necessary. ${ }^{21}$ Some phrases do not even have a conjunction between their core phrases. The conjunctions that exist between the two core phrases become modifiers.

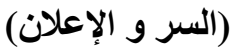

The phrase (السر و الإعلان) is one of the phrases that the researcher finds in the lyrics of the song on the Tabassam Album by Mesut Kurtis. This phrase belongs to the category of coordinating endocentric phrases with opposition. The phrase (السر الإعلان) has the meaning of clandestine and overt translation in Indonesian. The classification of this phrase into an endocentric phrase is due to the similarity in the distribution of its meaning and is classified as a coordinative classification because it has more than one central element. Meanwhile, the classification into opposition is due to clandestine opposition or the opposite of overt.

Here is the translation of the phrase in the construction phrase tagmemes endocentric coordinate with opposition:

Table 7. Shape endocentric Coordinating phrase

\begin{tabular}{cccc}
\hline phrase & $($ الإعلان) & $(g)$ & $($ Hiding discreetly \\
\hline Translations & Blatant & And & Ism \\
\hline Category & Ism & Harf Athaf & CenterElements \\
\hline Function & ElementCenter & Kata Contacts & Conten
\end{tabular}

The phrase (السر و الإعلان) is located in the sentence (احمده فى السر و الإعلان) which means I praise you secretly and openly. The structure of the type of coordinating endocentric phrase with the opposition in the two central elements is as follows:

FEKo (tarkib 'athfi) $=\mathrm{I}+\mathrm{A}+\mathrm{I}$

In the formula it is explained that FeKo (coordinative endocentric phrase) or in Arabic terms is called tarkib 'athfi is composed of tagmeme I (Ism) as Up (central element) then tagmeme A ('Athaf) as a conjunction and another tagmeme I (Ism) as Up (central element) the second. The central tagmeme is the core of the tagmeme (nuclear) or the central element and is mandatory by Ism. The system unit tagmemes with four elements are described in the chart below:

Figure 5. Cosordinatingtagmemes endocentric phrase

\begin{tabular}{|c|c|}
\hline $\begin{array}{l}\text { Slot } \\
\text { السر والإعلان" } \\
\text { "Hide-hidden and overt" } \\
\text { feko = Up + Kh + Up } \\
\text { Slot (Up), both of which are core phrase }\end{array}$ & $\begin{array}{l}\text { classes } \\
\text { "السر والإعلان } \\
\text { "and overt" } \\
\text { CovertFEKo = I + M + I } \\
\text { It consists of two isms and one harf 'athaf }\end{array}$ \\
\hline $\begin{array}{l}\text { Role } \\
\text { السر والإعلان } \\
\text { Hiddenly "and openly" } \\
\text { The roles of the two core phrases have an } \\
\text { equivalent }\end{array}$ & $\begin{array}{l}\text { Cohesion } \\
\text { السر والإعلان } \\
\text { Tagmeme Hidden-“hidden and overt" The } \\
\text { the cohesion of this phrase is the equivalence } \\
\text { meaning. }\end{array}$ \\
\hline
\end{tabular}

${ }^{21}$ Benjamin Franklin Elson and Velma Pickett, Beginning Morphology and Syntax (Summer Inst of Linguistics, 1983). 
Based on diagram 5. Coordinative Endocentric Phrase Tagmeme is clearly illustrated by four scopes of phrase tagmemic with slot, class, role, and cohesion. Here is the description:

a. Slots. In the first dimension, namely slots, phrases (السر و الإعلان) have slots which are built by a structure with the arrangement of central elements, conjunctions, and other central elements $(\mathrm{FEKo}=\mathrm{Up}+\mathrm{Kh}+\mathrm{Up})$. The slot that is one of the characteristics of tagmeme is a space in its structure filled by the tagmeme function. Meanwhile, the tagmemic function in the phrase is in the form of the nucleus and the outside of the core (margin). Slots are the same as functions or sentence positions. The fulfillment of the slot with the core of the phrase which is the central element (Up) in the phrase (السر الإعلان) is (السر) which means secretly and (الإعلان) which means openly. At the same time, the outer core is a conjunction (Kh), namely (و) which means and.

b. Class. In the class dimension, the phrase tagmeme fills the slot with three categories: isim, harf 'athaf, and isim maushul. Class is a feature of tagmeme in the form of a natural form of slot filler. Classes in phrases are filled with lingual units such as words, morphemes, and phrases. These lingual units are class categories. Classes can be further broken down into subclasses or smaller classes. In phrases, classes can be broken down into noun phrases (object phrases) and verb phrases (working phrases). The phrase (السر والإعلان) is a noun phrase. The class category that fills this phrase is Ism, i.e. (السر الإعلان) in the central element slot (Up) and the letter 'athaf is the phrase (و) in the conjunction (Kh).

c. The role. In the role dimension, the phrase tagmemic is carried by the tagmeme function. A role is a tagmeme marker or a feature that is a carrier of the tagmeme function. The phrase (السر والإعلان) each tagmemic has a role as an actor (actor). The ism class category serves as the central Element (Up) actor. While the letter 'athaf becomes a modifier that limits and develops the meaning of the central element. ( ، (و) becomes the carrier of the function of the nucleus (nucleus), and (السر، الإعلان carries the function outside the nucleus (margin). In endocentric phrases, semantically the phrase (السر والإعلان) has an equivalent function between its central elements.

d. Cohesion. In the fourth dimension, cohesion becomes a controller of continuity in the tagmeme-tagmeme on the phrase. Cohesion is a tagmeme marker that has control over the link between tagmemics. The controller of the coordinative endocentric relationship is the equivalence of the meanings of the principal elements of the two isms.

\section{Construction of Apositive Endocentric Phrases in the Tabassum Album}

Apositive Endocentric Phrases are phrases that consist of two cores, and both have no similar referent in them and are not connected by a Conjunction, which means conjunction or conjunction. The construction of the positive endocentric phrase in Arabic rules is also called tarkib isim or tarkib dzorof.

There is 1 apositive endocentric phrase found in the lyrics of Mesut Kurtis's Tabassam Album which is summarized in the table below:

Table 8. Appositive Endocentric Phrases Grammatical 
أحمد حبيينا عليك السلام Phrases Appositive endocentric phrases with direct phrases as taukid (explanatory)

In Table 8. There is only one indicator of the appositive endocentric phrase in the form of the appositive phrase, namely, the appositive endocentric phrase with the phrase directly as taukid (explanatory). By translating the phrase tagmemes as follows:

(أحمد حبيينا)

The following translation of a phrase in the construction tagmemes endocentric positive phrase:

Table 9. Endocentric Appositif Phrase

\begin{tabular}{lll}
\hline phrase & $($ أحمد) & (حبينا) \\
\hline Translate & Ahmad & Lovers us \\
\hline Categories & Ism & Ism dzorof (sinking) \\
\hline Function & ElementCenter (UP) & The Central Element of the \\
\hline
\end{tabular}

Phrase (أحمد حبينا) which means "Ahmad Kekasih kita" is located in the lyrics of the song (أحمد حبينا عليك السلام). It is called the positive endocentric phrase because its composition contains two core words in the form of Ism as the central element. The noun one is the central element (UP), and the other word also becomes the central element (UP) which describes the state of the first central element. The explanation of the formula is as follows:

FEAp = I + I / N + N.

FEAp (positive endocentric phrase) two core elements contradict each other but are explanatory of one and the other, including the direct a positive, which is not followed by any conjunction. The central tagmeme is the core of the tagmeme (nuclear) or central element and is mandatory to be filled by the Ism. The following is a tagmeme system with four elements described in the chart below:

Diagram 6. Tagmemic Apositive Endocentric Phrase

\begin{tabular}{|c|c|}
\hline $\begin{array}{l}\text { Slot } \\
\text { (أحمد حبيينا) }\end{array}$ & $\begin{array}{l}\text { Class } \\
\text { (أحمد حبيينا) }\end{array}$ \\
\hline "Ahmad Our Beloved" & "Ahmad Our Beloved" \\
\hline $\mathrm{FEAp}=\mathrm{UP}+\mathrm{UP}$ & FEAp = I + I / N + N \\
\hline $\begin{array}{l}\text { Slot (Up) is the core of the phrase. There are two } \\
\text { core phrases in the word }\end{array}$ & $\begin{array}{l}\text { It consists of two isms that are interrelated in } \\
\text { explaining the phrase }\end{array}$ \\
\hline $\begin{array}{l}\text { Role } \\
\text { (أحمد حبينا) }\end{array}$ & $\begin{array}{l}\text { tagmemic cohesion } \\
\text { (أحمد حبينا) }\end{array}$ \\
\hline $\begin{array}{l}\text { "Ahmad Our Beloved" } \\
\text { Both core phrases have equivalent and } \\
\text { interconnected }\end{array}$ & $\begin{array}{l}\text { "Ahmad Our Beloved" } \\
\text { No word separates them (connectors, etc.), but the } \\
\text { two words are parallel. }\end{array}$ \\
\hline
\end{tabular}

Based on Diagram 6. Tagmemic Appositive Endocentric Phrase depicts four tagmemic elements in it:

a. Slot. In the first dimension, the phrase slot builds a structure with the first order, the phrase (أحمد حبيينا) has a slot built by the structure of the central element and attributes in the form of pronouns. FEAp $=\mathrm{I}+\mathrm{I} / \mathrm{N}+\mathrm{N}$. The slot that is one of the features of tagmeme is a space in the structure that is filled by the tagmeme function. At the same 
time, the function of tagmeme in the phrase is the core (nucleus) and outside the core (margin). Slots are the same as the function or sentence positions. Filling the slot with the core of the phrase that is the central element (Up) in the phrase (أحمد حبيينا) is (أحد) which means ahmad as an external temporary name, the essence is the name taukid or explanatory (حبينا) which means my beloved so that Ahmad Kekasihku said.

b. Class. In the class dimension, the phrase tagmeme fills the slot with both categories. The class on the phrase is filled with lingual units such as words, morphemes, and phrases. These lingual units are class categories. Classes can be further broken down into subclasses or smaller classes. In phrases, classes can be broken down into noun phrases (object phrases) and verb phrases (working phrases). The phrase (أحمد حبيينا) is a noun phrase. In the second dimension, the class consists of two categories, namely ism (أحمد) as the central element and the pronoun (حبينا) as the supporting element that fulfills the position of the tagmeme class.

c. The role. In the role dimension, the phrase tagmeme is carried by the tagmeme function. A role is a tagmeme marker or a feature that is a carrier of the tagmeme function. The phrase (أحمد حبيينا) each tagmeme has a role as an actor (actor). The ism class category serves as the central Element (Up) actor. While the isim shifat becomes the perpetrator of modifications that limit and develop the meaning of the central element. (أحمد) becomes the carrier of the core function (nucleus) and (حبينا) carries the function outside the core (margin). In endocentric phrases, semantically the phrase has an equivalent function between its central elements.

d. Cohesion. In the fourth dimension, cohesion becomes a controller of continuity in the tagmeme-tagmeme on the phrase. Cohesion is a tagmemic marker that has control over the link between tagmemics. The controller of the positive endocentric relationship is an explanation of the meaning of the principal element of the Ism. In the table above, the positive endocentric phrase has no conjunction between them because they are both a unit of meaning that complements and controls the phrase in it. The cohesion of the tagmeme in this phrase is the equality of the distribution of meaning between the modifier and the core of the phrase.

\section{CONCLUSION}

The song lyrics on the Tabassam Album by Mesut Kurtis, which consists of 12 songs, contains endocentric phrases with three types, namely: (1) Attributive endocentric phrases with a total of five phrases; (2) Coordinative endocentric phrases with five phrases; and (3) Apositive endocentric phrases with one phrase. These three types of phrases have various structures. Coordinative endocentric phrases have three different forms of structure, namely: (1) Endocentric phrases with opposition (I + A + I); (2) Endocentric phrases with development $(\mathrm{I}+\mathrm{A}+\mathrm{I})$; and (3) Endocentric phrases without conjunctions $(\mathrm{I}+\mathrm{I})$. While in the attributive endocentric phrase, there are three different forms of structure, namely: (1) Endocentric phrase with adjectives (I + S/ N + Adj); (2) Endocentric phrases with pronouns ( + Dh / N + ProN); and (3) Endocentric phrases with parallel nouns $(\mathrm{I}+\mathrm{I})$. Apositive phrase has one formula, namely, $\mathrm{I}+()+,\mathrm{I} / \mathrm{N}+()+,\mathrm{N}$.

This study reveals the tagmemic of the phrase in the song Mesut Kurtis in the album Tabassam. Kenneth Lee Pike's theory is very rich in tagmemics classifications and enjoyable to continue to explore. This study can still not explain the entire classification of tagmeme, especially on tagmemic theory based on Pike's perspective. Therefore, researchers suggest continuing to dig into the study of tagmemics extensively and indefinitely. 


\section{REFERENCES}

Anitha, J., J. Saritha, and Namkyun Baik. "Payroll Processing Tagmemics in SAP HR." International Journal of Advanced Science and Technology 111 (2018). https://doi.org/10.14257/ijast.2018.111.06.

Bodine, Walter R., and David Allan Dawson. "Text-Linguistics and Biblical Hebrew." Journal of the American Oriental Society, 1997. https://doi.org/10.2307/605294.

Bogdan, R., and S Knopp. "Qualitative Research for Education." Qualitative Research, 2003. https://doi.org/10.1177/1468794107085301.

Cook, Walter Anthony. Introduction to Tagmemic Analysis. Holt McDougal, 1969.

Elson, Benjamin Franklin, and Velma Pickett. Beginning Morphology and Syntax. Summer Inst of Linguistics, 1983.

Flower, Linda, and John R. Hayes. "The Cognition of Discovery: Defining a Rhetorical Problem." College Composition and Communication, 1980. https://doi.org/10.2307/356630.

Hasyim, Muhammad, Asbarin Asbarin, and Hammadul Azhim. "Konstruksi Sintaksis Dalam Novel" Bumi Cinta" Karya Habiburrahman El Shirazy Berdasarkan Perspektif Tagmemeik Kenneth L. Pike," 2020.

Hidayah, Arini. "Frase Nomina Pelaku Endosentris Atributif Bahasa Inggris Di Bidang Kantor Depan (Front Office) Hotel." Haluan Sastra Budaya 3, no. 2 (n.d.).

Hincha, Georg. "Endocentric vs. Exocentric Constructions." Lingua, 1961. https://doi.org/10.1016/0024-3841(61)90132-2.

Husin, Ahmad, and Roihanah Husin. "Peran Teori Tagmemeik Dalam Pembelajaran Sastra Anak Khususnya Penggunaan Media Lagu-Lagu Dolanan.” JURNAL PUSAKA 2, no. 2 (2015).

Martin, James R. "Text and Clause: Fractal Resonance." Text-Interdisciplinary Journal for the Study of Discourse 15, no. 1 (1995).

Parera, Jos Daniel. "Sintaksis (Edisi Kedua)." Jakarta: PT Gramedia Pustaka Utama, 1988.

Ramlan, Muhammad. Ilmu Bahasa Indonesia: Sintaksis. UP Karyono, 1981.

Rosliana, Lina. "Frasa Endosentris Pada Bahasa Jepang." Izumi 4, no. 1 (2015).

Shibatani, Masayoshi. "Syntax (General).” In International Encyclopedia of the Social \& Behavioral Sciences: Second Edition, 2015. https://doi.org/10.1016/B978-0-08097086-8.52033-9. 